\title{
The Importance of Ambulatory Venous Hypertension Should Be Revised
}

\author{
Jiř̌́ Spáčil \\ Angiology Department, Spamed, Prague, Czech Republic \\ Email address: \\ drjirispacil@seznam.cz

\section{To cite this article:} \\ Jiří Spáčil. The Importance of Ambulatory Venous Hypertension Should Be Revised. Cardiology and Cardiovascular Research. \\ Vol. 3, No. 1, 2019, pp. 14-17. doi: 10.11648/j.ccr.20190301.14
}

Received: January 6, 2019; Accepted: February 27, 2019; Published: March 26, 2019

\begin{abstract}
Inadequate decrease of venous pressure in patients with varicose vein while walking and exercising is called ambulatory venous hypertension (AVH). It has been considered as the main cause of chronic venous insufficiency. However, venous pressure in lower limbs while standing $(95 \mathrm{mmHg})$ and sitting $(70 \mathrm{mmHg})$ remains higher most of the day compared to AVH (healthy persons $26 \mathrm{mmHg}$, patients with varicose veins $41 \mathrm{mmHg}$ ). Published values of venous pressure in lower limbs in healthy persons and in patients with varicose veins in lower limbs, obtained while lying, standing, standing with small movements, sitting and walking, and the reported times, were used to calculate the mean venous pressure for 24 hours. Photoplethysmographic testing was used for indirect evaluation of venous haemodynamics in intensive and moderate exercise in sitting subjects. Patients with varicose veins restrict standing times; taking into account this fact, mean venous pressure for 24 hours reached $48.71 \mathrm{mmHg}$ in healthy persons and $49.56 \mathrm{mmHg}$ in patients with varicose vein (CEAP C2 stage). The difference is very small and cannot be the fundamental pathophysiological mechanism of development of venous insufficiency. Conclusion: 24-hour venous pressure in legs in healthy persons and in persons with varicose veins in lower limbs shows only a very small difference. The importance of $\mathrm{AVH}$, particularly in initial stages of the disease, should be revised.
\end{abstract}

Keywords: Ambulatory Venous Hypertension, Venous Pressure, Varicose Vein

\section{Introduction}

Nowadays venous hypertension has been generally recognized as the fundamental pathophysiological mechanism of development of chronic venous insufficiency [1-3]. In the standing and sitting positions, venous pressure in lower limbs is increased by hydrostatic pressure. In healthy persons, this pressure decreases substantially while walking and exercising. In patients with varicose veins, its decrease is lower, and the pressure may even increase in the most severe cases. Increased venous pressure while exercising in patients, compared to healthy persons, is called venous hypertension. A more precise term would be ambulatory venous hypertension (AVP). The most common causes include a venous disorder (valvular insufficiency, venous obstruction or both), reduced performance of the muscle pump of the calf and foot for various reasons and others, for example, elevated intraabdominal pressure. It has been demonstrated that the more severe the chronic venous disease is, assessed e.g. based on CEAP classification [4], the higher AVP values are.
And the higher AVP values, the higher the probability of a more serious disease, particularly skin ulcerations [5-7]. However, patient groups overlap considerably, showing clearly that other factors also play a role in addition to AVP. Particularly, the following factors have been reported: the age, family history, obesity, female sex, pregnancy, as well as high or low physical activity, standing or sitting. The condition of the lymphatic system, that of microcirculation, and readiness for an inflammatory reaction upon damage, etc. play a role, as well. When the pressure in venules and capillaries increases in the skin of lower limbs, microangiopathy starts to develop, which progresses in time. Capillary filtration and diffusion increase, an oedema is formed, thrombosis in the capillaries appears and their density decreases. Oxygen tension also decreases. Fibrin layers form around the capillaries, and lymph capillaries are damaged. Pigmentation develops given the presence of haemosiderin after minor extravasation episodes. More proteins start entering the interstitium and a sterile inflammation develops. Fibrous tissue proliferation, scarring 
and atrophy of the skin occur. Oedema predominates in same patients, and induration or atrophy of the skin and subcutis in others. Crural ulcer develops after a minor injury. In recent decades, chronic inflammatory reaction has been the subject of very detailed study. Activated endothelium increases the formation of adhesive molecules, allowing for higher rates of attachment of monocytes and macrophages and their penetration in tissues. Formation of growth and procoagulation factors and proteolytic enzymes also increases. Oxidative stress rises, which is also contributed by ferritin from the entered erythrocytes. The chronic inflammatory cascade is a protective mechanism that can be viewed as balancing on the edge between damage and healing, and various influences (standing, obesity, inactivity) including genetic ones cause the balance to deflect to one or the other side.

Considering the effect of AVP, it should be realized that for most of the day, the pressure in veins while standing or sitting is higher than while walking - an activity performed only for a limited time in the day. We calculated the mean venous pressure for 24 hours in healthy persons and in persons with varices.

\section{Methods}

Published data on venous pressure in lower limbs and time spent in the lying, sitting and standing positions and during walking were chosen from the literature (Table 1, 2). The average number of steps per day in USA is about 7000, in Europe 10000 [14]. Usual frequency of walking is 100 steps per minute and walking time 100 minutes. After stopping, venous pressure return slowly to default pressure and therefore we used the walking time 120minute per day in our calculation. In regular life, persons are not at complete rest while standing and sitting. For standing and small moving we used a half of standing time and pressure for little walking $(0$, $5 \mathrm{~m} / \mathrm{h}$ ) [7]. It is generally known, that subjects with venous disease reduced standing position and prolong laying position as shown, for example by Eiffel [6]. We incorporated this fact in our calculation. We found no data for venous pressure in sitting position and small movements. We assessed this situation by photoplethysmography [2].

Table 1. Venous pressure in $\mathrm{mmHg}$ on the top of the foot or at the inner ankle in persons in the lying, sitting and standing position. $*=$ calculation from values obtained during measurement on a bed tilted down to 30 and 70 degrees. In [ ] number of references.

\begin{tabular}{|c|c|c|c|c|c|}
\hline Author & Examined persons & Number & $\begin{array}{l}\mathrm{BP}(\mathrm{mmHg}) \text { in } \\
\text { the lying position }\end{array}$ & $\begin{array}{l}\mathrm{BP}(\mathrm{mmHg}) \text { in the } \\
\text { sitting position }\end{array}$ & $\begin{array}{l}\mathrm{BP}(\mathrm{mmHg}) \text { in the } \\
\text { standing position }\end{array}$ \\
\hline \multirow[t]{2}{*}{ Pollack, 1949 [8] } & Healthy & 7 & 7.2 & 58.8 & 90.5 \\
\hline & With varices & 10 & 10.7 & 52 & 81.9 \\
\hline Stick, 1992 [9] & Healthy & 18 & & & 84 \\
\hline Christ, 1997 [10] & Healthy & 9 & 8.8 & & \\
\hline Kügler, 2001 [11] & $\begin{array}{l}\text { Healthy Height: } 175 \mathrm{~cm} \& \text { less } \\
\text { Over } 175\end{array}$ & 20 & & & $\begin{array}{l}95 \\
92 \\
101\end{array}$ \\
\hline van Rij, 2008 [12] & Healthy & 14 & 12 & 70 & 93 \\
\hline Groothuis, 2008 [13] & Healthy & 12 & & $62 *$ & $90.1 *$ \\
\hline
\end{tabular}

Table 2. Venous pressure in lower limbs while walking in healthy persons and in patients with venous varices in lower limbs while walking. $m / h=m i l e s / h o u r ;$ C2, = clinical stages according to CEAP classification [4]. In [ ] number of references.

\begin{tabular}{|c|c|c|}
\hline & Healthy & Patients with venous varices in lower limbs. \\
\hline Pollack, 1949 [8] & $\begin{array}{l}22.3(11-31) \mathrm{mmHg}, 1.7 \mathrm{~m} / \mathrm{h} \\
\mathrm{n}=11\end{array}$ & 43.7, (34-56) $\mathrm{mmHg}, 1.7 \mathrm{~m} / \mathrm{h}$ \\
\hline Stick, 1992 [9] & $\begin{array}{l}23.5 \mathrm{mmHg} 3 \mathrm{~km} / \mathrm{h} \\
30.4 \mathrm{mmHg} 6 \mathrm{~km} / \mathrm{h} \\
29.5 \mathrm{mmHg} 10 \mathrm{~km} / \mathrm{h}\end{array}$ & \\
\hline Kügler, 2001 [11] & $\begin{array}{l}38.1 \mathrm{mmHg} 1.5 \mathrm{~km} / \mathrm{h} \\
28.6 \mathrm{mmHg} 3 \mathrm{~km} / \mathrm{h}\end{array}$ & \\
\hline
\end{tabular}

\section{Results}

Venous pump power while stepping from one foot to the other in the sitting position is very small and very probably there is no substantial decrease of venous pressure (table 3). From this reason we used one venous pressure value for sitting subjects

Table 3. Investigation of venous pump in sitting position by quantitative digital photoplethysmography. Number of legs: 100 , average age 57 years, $60 \%$ of women, average CEAP classification: 1,7. SD: standard deviation.

\begin{tabular}{|c|c|c|c|c|c|c|}
\hline & $\mathbf{n}$ & & $\begin{array}{l}\text { Dorsal flexion of foots. } \\
\text { Sitting position }\end{array}$ & $\begin{array}{l}\text { Stepping from one foot to the } \\
\text { other. Sitting position }\end{array}$ & Difference & $\begin{array}{l}\text { Statistical } \\
\text { significance }\end{array}$ \\
\hline Vo (venous pump power) (\%) & 100 & Mean SD & $4,723,13$ & $0,88(13 \%) 0,91$ & $-3,48$ & $\mathrm{P}<0,001$ \\
\hline Fo (venous pump work) $(\% \mathrm{~S})$ & 100 & Mean SD & 64,3641 & $2,46(3,8 \%) 6,8$ & $-61,9$ & $\mathrm{P}<0,001$ \\
\hline
\end{tabular}


Venous pressures and time spent in different position and mean pressures are presented in table 4 . The mean venous pressure/24 hours in healthy subjects is $48,7 \mathrm{mmHg}$ and in patients with varicose veins it is $49,6 \mathrm{mmHg}$. The venous pressure is almost the same. Patients with varicose veins reduce their standing position times causing high foot venous pressure and this compensates a little the higher venous pressure while walking.

Table 4. Venous pressure during lying, standing, sitting and walking in healthy subjects and in patients with varicose vein (CEAP classification 2$) . h=$ hour. In [] number of references.

\begin{tabular}{lllll}
\hline & Healthy subjects & Venous disease \\
\cline { 2 - 5 } & Time (h) & Venous pressure (mmHg) & Time (h) \\
\hline Lying & $6[6]$ & $12(12)$ & $8[6]$ & Venous pressure (mmHg) \\
Standing-rest & 5 & $95[11]$ & 3,5 & 12 \\
-small movement & 5 & $30[7]$ & 3,5 & $95[11]$ \\
Sitting & $6[6,16]$ & $70[12]$ & $7[6]$ & $54[7]$ \\
Walking & $2[14,17]$ & $26[7,14]$ & 2 & $70[12]$ \\
Mean venous Pressure/24h & & 48,71 & $41[7,8]$ & 49,56 \\
\hline
\end{tabular}

\section{Discussion}

We did not measure venous pressure in legs. We used data from published papers to calculate the mean venous pressure in lower extremities. We chose data close to normal life. These calculations of mean venous pressures in the limbs show only small differences between healthy subjects and patients with varicose vein. This indicates that an elevated venous pressure while walking in patients with venous varices in lower limbs may not be the main cause of chronic venous insufficiency. This is also supported by the fact that as far as we know, no evidence of any effect of the height of patients on chronic venous insufficiency has been found [18]. If venous hypertension is not involved in the development of chronic venous insufficiency, sheer stress may be the main factor, i.e. the force that acts on the endothelium during blood flow [3, 19]. It changes at the same moments when the speed and direction of the flow change, and in the cause of turbulent flow. Sheer stress has been studied in detail and profoundly predominantly in arteries in connection with the study of atherosclerosis [20]. Marked changes of the flow occur in veins upon changes in the position, during exercise, cough, and especially in valvular insufficiency. Sheer stress has a significant effect on the endothelium, particularly around valves and probably also in microcirculation [21]. Increased sheer stress exerts load on the endothelium, which may lead to its damage (both functional and morphological); low sheer stress facilitates the formation of thrombi. Endothelial dysfunction leads to the aforementioned cascade of processes in microcirculation $[2,22]$ and also in valves [23, 24]. Chronic inflammation leading primarily to protection of the venous wall may, in the event of permanent stimuli, cause further dilatation of varicose veins and valvular insufficiency, and thus further increase of sheer stress.

\section{Conclusion}

Twenty four hour venous pressure in lower legs in healthy persons $(48,71 \mathrm{mmHg})$ and in persons with varicose veins $(49,56 \mathrm{mmHg})$ is almost same. The importance of ambulatory venous hypertension, particularly in initial stages of the varicose vein formation, should be revised.

\section{References}

[1] Raffetto JD. Pathophysiology of chronic venous disease and venous ulcers. Surg Clin North Am 2018; 98: 337-347.

[2] Mansilha A, Sousa J. Pathophysiological mechanisms of chronic venous disease and implications for venoactive drug therapy. Int J Mol Sci 2018; 19, 1669; doi: 10.3390/ijms 19061669.

[3] Labropoulos N. How does chronic venous disease progress from the first symptoms to the advanced stages? A review. Adv Ther. 2019 Feb 13. doi: 10. 1007/s12325-019-0885-3.

[4] Eklöf B, Rutherford RB, Bergan JJ, Carpantier PH, Gloviczki $\mathrm{P}$, Kistner RL et al. Ad hoc committee for revision of the CEAP classification. Revision of the CEAP classification for chronic disorders: consensus statement. J Vasc Surg 2004; 40: 1248-52.

[5] Nicolaides AN, Hussein MK, Szendro G, Christopoulos D, Vasdekis $\mathrm{S}$ and Clarke $\mathrm{H}$. The relation of venous ulceration with ambulatory venous pressure measurements. J Vasc Surg 1993; 17: 414-9.

[6] Eifell RKG, Ashour HY, Heslop PS, Walker DJ and Lees TA. Association of 24-hour activity levels with the clinical severity of chronic venous disease. J Vasc Surg 2006; 44: 5807.

[7] Eifell RKG, Ashour HY, Lees TA: Comparison of new continuous measurements of ambulatory venous pressure (AVP) with conventional tiptoe exercise ambulatory AVP in relation to the CEAP clinical classification of chronic venous disease. J Vasc Surg 2006; 44: 794-802.

[8] Pollack AA, Taylor BE, Myers TT a Wood EH: The effect of exercise and body position on the venous pressure at the ankle in patients having venous valvular defects. J Clin Invest 1949; 28: $559-563$.

[9] Stick C, Jaeger H, Witzleb E. Measurement of volume changes and venous pressure in the human lower leg during walking and running. J Appl Physiol 1992; 72: 2063-8.

[10] Christ F, Gamble J, Baschnegger H, Gartside IB. Relationship between venous pressure and tissue volume during venous congestion plethysmography in man. J Appl Physiol 1997; 503: 463-467. 
[11] Kügler C, Strunk M, Rudovsky G. Venous pressure dynamics of the healthy human leg. J Vasc Res 2001; 38: 20-29.

[12] van Rij AM, De Alwis CS, Jiang P, Christie RA, Hill GB, Dutton SJ, Thomson IA. Obesity and impaired venous function. Eur J Vasc Surg 2008; 35: 739-744.

[13] Groothuis JT, Poelkens F, Wouters CW, Kooijman M. Leg intravenous pressure during head-up tilt. J Appl Physiol 2008; 105: 811-815.

[14] Sequeira MM, Rickenbach M, Wietlisbach V, Tullen B, Schutz Y. Physical activity assessment using a pedometer and its comparison with a questionnnaire in a large population survey. Am J Epidemiol 1995; 142: 989-99.

[15] De Cocker K, Cardon G, De Bourdeaudhuij I. Pedometerdetermined physical activity and its comparison with the international physical activity questionnaire in a sample of Belgian adults. Res Q Exerc Sport 2007; 78: 429-37.

[16] Miller R, Brown W. Steps and sitting in working population. Int J Behav Med 2004; 4: 219-24.

[17] McCormack G, Giles-Corti B, Milligan R. Demographic and individual correlates of achieving 10000 steps /day: use of pedometers in population -based study. Health Promot J Austr. 2006; $1: 43-7$.

[18] Spáčil J, Svobodová J. Does body height affect the severity of chronic venous disease in lower extremities? Vnitr Lék 2015; 61: 202-206.
[19] Comerota AJ. Treatment of chronic venous disease of the lower extremities: what's new in guidelines? Phlebolymphology 2009; 16: 313-320.

[20] Davies PF: Hemodynamic shear stress and the endothelium in cardiovascular pathophysiology. Nat Clin Pract Cardiovasc Med 2009; 6: 16-26.

[21] Vincent JR, Jones GT, Hill GB, van Rij AM. Failure of microvenous valve in small superficial veins is a key to the skin changes of venous insufficiency. J Vasc Surg 2011; 54: 62S-9S.

[22] Ligi D, Croce L, Mannello F. Chronic venous disorders: The dangerous, the good, and the diverse. Int J Mol Sci 2018; 19, 2544; doi: 10.3390/ijms 19092544.

[23] Ono T, Bergan JJ, Schmid-Schönbein GW, Takase S. Monocyte infiltration into venous valves. J Vasc Surg 1998; 27: 158-66.

[24] Mouton WG, Habegger AK, Haenni B, Tschanz S, Baumgartner I, Ochs M. Valve disease in chronic venous disorders: a quantitative ultrastructural analysis by transmission electron microscopy and serology. Swiss Med Wkly 2013; 143: w13755. 